University of Nebraska - Lincoln

DigitalCommons@University of Nebraska - Lincoln

Virology Papers

Virology, Nebraska Center for

January 2002

\title{
Cellular Tropisms and Co-receptor Usage of HIV-1 Isolates from Vertically Infected Children With Neurological Abnormalities and Rapid Disease Progression
}

\author{
Micheline McCarthy \\ Department of Veterans Affairs Medical Center, Miami, Florida \\ Jun $\mathrm{He}$ \\ University of Nebraska-Lincoln \\ Denise Auger \\ Department of Veterans Affairs Medical Center, Miami, Florida \\ Rebeca Geffin \\ University of Miami School of Medicine \\ Cecilia Hutto \\ University of Miami School of Medicine \\ See next page for additional authors
}

Follow this and additional works at: https://digitalcommons.unl.edu/virologypub

Part of the Virology Commons

McCarthy, Micheline; He, Jun; Auger, Denise; Geffın, Rebeca; Hutto, Cecilia; Wood, Charles; and Scott, Gwendolyn, "Cellular Tropisms and Co-receptor Usage of HIV-1 Isolates from Vertically Infected Children With Neurological Abnormalities and Rapid Disease Progression" (2002). Virology Papers. 75.

https://digitalcommons.unl.edu/virologypub/75

This Article is brought to you for free and open access by the Virology, Nebraska Center for at DigitalCommons@University of Nebraska - Lincoln. It has been accepted for inclusion in Virology Papers by an authorized administrator of DigitalCommons@University of Nebraska - Lincoln. 
Authors

Micheline McCarthy, Jun He, Denise Auger, Rebeca Geffin, Cecilia Hutto, Charles Wood, and Gwendolyn Scott 


\title{
Cellular Tropisms and Co-receptor Usage of HIV-1 Isolates from Vertically Infected Children With Neurological Abnormalities and Rapid Disease Progression
}

\author{
Micheline McCarthy, ${ }^{1,2,3} *$ Jun He, ${ }^{5}$ Denise Auger, ${ }^{1,2}$ Rebeca Geffin, ${ }^{4}$ Cristina Woodson, ${ }^{4}$ \\ Cecelia Hutto, ${ }^{4}$ Charles Wood, ${ }^{5}$ and Gwendolyn Scott ${ }^{4}$ \\ ${ }^{1}$ Department of Veterans Affairs Medical Center, Miami, Florida \\ ${ }^{2}$ Department of Neurology, University of Miami School of Medicine, Miami, Florida \\ ${ }^{3}$ Department of Microbiology and Immunology, University of Miami School of Medicine, Miami, Florida \\ ${ }^{4}$ Department of Pediatrics, University of Miami School of Medicine, Miami, Florida \\ ${ }^{5}$ Nebraska Center for Virology and the School of Biological Sciences, University of Nebraska, Lincoln, Nebraska
}

The longitudinal evolution of HIV-1 phenotypes was studied in a cohort of six vertically infected children with early onset and rapid progression of clinical disease. Among 30 viral isolates obtained from peripheral blood, tropisms for both human blood-derived cells (macrophages, T-lymphocytes), and for human neural (brain-derived) cells (microglia, astrocytes) were determined, as was chemokine co-receptor usage. All children harbored from birth macrophage-tropic isolates using the CCR5 co-receptor. Two children later developed T-cell tropic isolates with CXCR4 and CCR3 usage. While all six patients developed neurological abnormalities, only three produced neural cell tropic isolates, which used CCR5. However, early and persistent finding of both astrocyte- and microglia-tropic isolates in one patient did associate with the most rapid progression to brain atrophy among the six patients. Viral phenotypic properties determined in cell culture did not specifically predict clinical features or course, and the development of AIDS did not coincide with, or depend on, the appearance T-tropic, syncytia-inducing viruses. J. Med. Virol. 67:1-8, 2002.

KEY WORDS: HIV-1 infections; pediatrics; neuroglia; astrocytes; macrophages; chemokine receptors

\section{INTRODUCTION}

Children with human immunodeficiency virus type 1 (HIV-1) infection may develop a broad spectrum of clinical disease that is variable in both age at onset of serious disease and progression [Blanche et al., 1990, 1994; Newell, 1991]. Most pediatric infection is acquired perinatally and, in infants, HIV-1 disease progression may be influenced by the timing of virus transmission to the infant, i.e., in utero or intrapartum. Rapid disease progression is reported in $10-20 \%$ of infected infants, and is more probable with in utero transmission [Dickover et al., 1994; Mayaux et al., 1996; Kuhn et al., 1997]. These infants are more likely to have an accelerated decline in their CD4+ lymphocyte counts, experience early developmental delay, develop AIDS defining conditions, and die before 4 years of age [Scott et al., 1989; Blanche et al., 1990; Newell, 1991; Duliege et al., 1992; Tovo et al., 1992; Turner et al., 1993]. Other children have a later onset and slower progression of disease, with a slower decline in immune function and longer survival [Auger et al., 1988; Scott et al., 1989; Blanche et al., 1990; European Collaborative Study, 1991; Duliege et al., 1992; Blanche et al., 1994; Italian Registrar, 1994]. In the current era of highly active antiretroviral therapy and early HIV-1 diagnosis, it is anticipated that fewer infants will develop encephalopathy and rapid disease progression.

Grant sponsor: National Institutes of Health (NIAID); Grant numbers: R01 AI/HD34337, RO1 AI23524; Grant sponsor: National Institutes of Health (NCRR); Grant number: P20 RR15635; Grant sponsor: Department of Veterans Affairs; Grant number: Merit Review Award 5538-04.

Cecelia Hutto's present address is Department of Pediatrics, University of Alabama School of Medicine, Birmingham, Alabama.

Denise Auger's present address is Dept. of Medicine, Children's Hospital, Harvard Medical School, Boston, Massachusetts.

*Correspondence to: Dr. Micheline McCarthy, Neurology (127), Miami Veterans Affairs Medical Center, 1201 NW 16th Street,

Miami, FL 33125. E-mail: mmccarth@med.miami.edu

Accepted 16 November 2001

DOI 10.1002/jmv.2185

Published online in Wiley InterScience

(www.interscience.wiley.com). 
Vertical transmission of HIV-1 may be associated with a phenotypically homogeneous population of viruses at birth [McNearney et al., 1992; Wolinsky et al., 1992; Mulder-Kampinga et al., 1993]. Then longitudinal changes may occur in HIV-1 viral genotype, i.e., the genetic sequence in certain viral genes, or in HIV-1 viral phenotype, i.e., the cellular tropisms and co-receptor usage. However, longitudinal changes in viral genotype or phenotype have not been definitively correlated with clinical disease progression in individual patients [Fitzgibbon et al., 1998]. The immune response and possibly other selective pressures may act on the viral envelope glycoprotein gene region during infection to drive the evolution of the virus population toward expanding cell tropisms and increased cytopathicity. Several studies, including our own, have shown that viral sequences in the envelope glycoprotein are more homogeneous early in infection, and sequence diversity increases with disease progression and a fall in CD4+ T-cell count [Hutto et al., 1996; Nowak and Bangham, 1996; Salvatori et al., 1997; Markham et al., 1998]. Most viruses isolated from adults and children close to the time of transmission are macrophage tropic and non-syncytium-inducing (NSI) [Roos et al., 1992; Spencer et al., 1994; Balotta et al., 1997], and they use predominantly chemokine receptor CCR5 as co-receptor [Zhang et al., 1998]. In older children and adults, the emergence of T-cell tropic, syncytium-inducing (SI) virus isolates using chemokine receptor CXCR4 and, in some cases, CCR3, is associated with rapid disease progression [Cheng-Mayer et al., 1989; Tersmette et al., 1989; De Rossi et al., 1993; Balotta et al., 1996; Coombs et al., 1996; Katzenstein et al., 1996; Koot et al., 1996; Fitzgibbon et al., 1998; Zhang et al., 1998]. During the first year of life, however, NSI isolates seem to predominate irrespective of clinical course [Spencer et al., 1994; van't Wout et al., 1994]. After progression of disease occurred, the majority of viral isolates acquired the ability to use CXCR4 and, in some cases, CCR3, while losing the ability to use CCR5.

While neurological illness is prominent in rapidly progressive pediatric HIV-1 infection, there are limited prospective data on viral tropisms for brain-derived cell types. Productive HIV-1 infection in the brain occurs in microglia, which are resident central nervous system (CNS) cells of monocyte origin [Bagasara et al., 1996]. In adults, HIV-1 isolates exhibit tropism for microglia that usually correlates with tropism for macrophages [Strizki et al., 1996] and the use of the CCR5 and CCR3 co-receptors [He et al., 1997]. In contrast, HIV-infection of astrocytes is restrictive or nonproductive, with very limited virus production and the predominant expression of nonstructural HIV proteins such as nef [Tornatore et al., 1991, 1994a,b; Blumberg et al., 1994; Ranki et al., 1995]. Cellular tropism for astrocytes loosely correlates with tropism for lymphocytes [McCarthy et al., 1998], and neurological disease during HIV-1 infection may result from neuronal and astrocyte apoptosis mediated by HIV-1 strains that interact with CXCR4 receptors on these neuroepithelial lineage cells
[Ohagen et al., 1999]. Restricted or nonproductive HIV-1 infection of astrocytes occurs in both pediatric and adult brains, suggesting that astrocytes function as a reservoir for latent virus in the CNS [Saito et al., 1994; Tornatore et al., 1994a; Ranki et al., 1995; Takahashi et al., 1996].

This study assesses the longitudinal evolution of cellular tropisms manifested by HIV-1 viruses isolated prospectively from a cohort of vertically infected children with early onset and rapid progression of clinical disease. The study specifically examines (1) tropisms for both human blood-derived cells (macrophages, $\mathrm{T}$ lymphocytes), and for human neural (brain-derived) cells (microglia, astrocytes); and (2) the corresponding longitudinal evolution of co-receptor usage by the viral isolates. These prospective data provide insight into the changes in viral phenotypic characteristics evolving early in the lifetimes of children with rapid HIV-1 disease progression.

\section{MATERIALS AND METHODS \\ Description of the Cohort}

A total of 35 children with perinatally acquired HIV infection were followed prospectively from birth. For all study patients, written informed consent was obtained from the child's parent or legal guardian. This study was approved by, and conducted according to the guidelines of the institutional review board of the University of Miami School of Medicine, the Medical Sciences Subcommittee for the Protection of Human Subjects. Clinical and laboratory data were collected every 3 months, and blood samples were drawn for HIV culture and plasma storage starting in the perinatal period and continuing throughout life. Six children with rapid disease progression were selected for this study based on having an adequate number of isolates to study. Rapid progressors had absolute CD4+ counts of $\leq 1,000 / \mathrm{mm}^{3}$ during the first year of life, or $\leq 500 / \mathrm{mm}^{3}$ during the second year of life, or had one or more of the AIDS defining criteria [Centers for Disease Control, 1994] during the first 2 years of life.

\section{Viral Assays}

HIV-1 viral load was determined in plasma using the standard Roche Amplicor HIV-1 Monitor Test (Roche Diagnostics Corporation, Indianapolis, IN). HIV-1 isolates were obtained by culture of the individual's peripheral blood mononuclear cells (PBMC) according to standard HIV-1 isolation techniques [AIDS Clinical Trials Group, 1994]. Virus production was monitored by measuring HIV-1 p24 antigen levels, using a commercial enzyme-linked immunoassay kit (Beckman Coulter, Hialeah, FL).

\section{Virus Titration and TCID $_{50}$ Calculation}

Virus stocks were prepared when p24 antigen exceeded $10 \mathrm{ng} / \mathrm{ml}$, and the titers were determined by limiting dilution to obtain the $50 \%$ tissue culture 
infectious dose $\left(\mathrm{TCID}_{50}\right)$ as described in the AIDS Clinical Trials Group (ACTG) virology manual for HIV laboratories, though with some modifications [AIDS Clinical Trials Group, 1994]. Briefly, serial fourfold dilutions of virus stocks, from 1:12 to 49,152 , in a final volume of $150 \mu \mathrm{l}$, were incubated in triplicates in flatbottomed 96 -well tissue culture plates with $50 \mu \mathrm{l}$ of phytohemagglutinin assay (PHA)-stimulated PBMC containing 200,000 cells, pooled from two uninfected donors. At day 4, $125 \mu \mathrm{l}$ of the culture media were removed and replaced with $150 \mu \mathrm{l}$ of fresh media. Supernatants were tested for the presence of p24 antigen at day 7 . The TCID $_{50}$ were calculated according to the Spearman-Karber method as described in the ACTG manual [AIDS Clinical Trials Group, 1994].

\section{Cell Culture}

Fetal CNS tissue for the preparation of astrocyte cultures was obtained from the Human Embryology Laboratory, University of Washington (Seattle, WA). Procedures for the procurement and use of human fetal CNS tissue were approved and monitored by the Medical Sciences Subcommittee for the Protection of Human Subjects of the University of Miami School of Medicine. Primary fetal human astrocyte monolayers were grown to $80 \%$ confluency on poly-L-lysine-coated 6 -well multicluster tissue culture dishes in B16 medium with $5 \mathrm{ng} / \mathrm{ml}$ basic fibroblast growth factor (bFGF) [McCarthy et al., 1995]. Primary human microglia were isolated from adult spinal cord and plated on uncoated 6-well tissue culture dishes in RPMI medium containing 5\% fetal bovine serum (FBS) [Whittemore et al., 1993]. The T-cell lines, MT-2, C8166, and CEM $\times 174$-GFP were cultured in RPMI medium-10\% FBS. Cell line HOS-CD4-CCR3 is from the NIH AIDS Research Reference and Reagent Program; it is propagated in DMEM medium containing $10 \% \mathrm{FBS}$, and $0.5-1.0 \mu \mathrm{g} / \mathrm{ml}$ puromycin. GhostCCR5 cells were propagated in DMEM with $10 \mu \mathrm{g} / \mathrm{ml}$ of hygromycin, $500 \mu \mathrm{g} / \mathrm{ml}$ of $\mathrm{G} 418$, and $1 \mu \mathrm{g} / \mathrm{ml}$ of puromycin. CEM $\times 174$-GFP and Ghost-CD4-CCR5 cells were supplied by Dr. Weidong Xu (Dana Farber Cancer Center, Boston, MA). Primary human monocytes were obtained from gradient-purified PBMC by the plastic adherent technique [Cheng-Mayer et al., 1989]. Adherent cells were cultured for 7-10 days in RPMI medium containing $10 \% \mathrm{FBS}$ and $10 \mathrm{ng}$ of granulocyte-macrophage colony-stimulating factor (GIBCO-BRL, Gaithersburg, MD) per $\mathrm{ml}$ to allow differentiation into macrophages.

\section{Determination of Cellular Tropism}

Each isolate was tested for its ability to infect primary human astrocytes (astrocyte tropism), primary human microglia (microglia tropism), the immortalized T-cell line MT-2 (T-cell tropism), and primary human macrophages (macrophage tropism). Virus isolates that were "T-tropic" were further monitored for syncytia induction (SI) in cell culture. Cells were first treated with $2 \mu \mathrm{g} / \mathrm{ml}$ Polybrene (Sigma Chemical Co., St. Louis, MO) for $1 \mathrm{hr}$ at $37^{\circ} \mathrm{C}$ and then incubated with the virus isolate at a multiplicity of infection (moi) of 500 TCID $_{50} /$ $10^{5}$ cells for $2 \mathrm{hr}$ at $37^{\circ} \mathrm{C}$. After this adsorption step, the cells were then washed and cultured in the appropriate medium. Supernatants were harvested at $0,3,7$, and 14 days postinfection from all infections except for astrocytes, in which case supernatants were harvested at 0 , $1,2,3,4$, and 7 days postinfection. Virus production was monitored by measuring the p24 antigen levels in the culture supernatants. Cultures were considered positive for viral growth if $>100 \mathrm{pg} / \mathrm{ml}$ of p24 was detected. A "weak positive" score was given if only 50$100 \mathrm{pg} / \mathrm{ml}$ of p24 was present, and a negative score if $<50 \mathrm{pg} / \mathrm{ml}$ was detected.

\section{Evaluation of Co-receptor Usage}

Determination of co-receptor usage was carried out using different cell lines expressing different coreceptors, CXCR4 (CEM $\times 174-\mathrm{GFP}$ cells $), \quad$ CCR5 (Ghost-CCR5 cells) and CCR3 (HOS-CD4-CCR3 cells) [Cecilia et al., 1998; Morner et al., 1999]. To test for co-receptor usage, all three cell lines were seeded at a density of $1 \times 10^{6}$ cells $/ \mathrm{ml}$ into each well of a 24-well plate, infected with $5 \mathrm{ng}$ p24 of HIV-1 per $\mathrm{ml}$ of cells, and on day 2-3 postinfection, the infected CEM $\times 174$ GFP and Ghost-CCR5 cells were observed under the microscope for marker green fluorescent protein (GFP) expression. A well containing three times or more green fluorescent cells than the negative control was considered positive. Negative control cells without HIV-1 infection generally produced only one to two GFP expressing cells per well. HIV-1 strains SF2 or NL4-3 was used as positive control for viruses that use CXCR4 as co-receptor, and HIV-1 strain SF128A was used as control for viruses that use CCR5 as co-receptor. Infection by the positive control virus usually gave at least 7 times more GFP-expressing cells than background control. For infection of HOS-CD4-CCR3, p24 virus production was monitored by measuring HIV-1 p24 antigen levels in the culture supernatants at 3 days postinfection. Cultures were considered positive for viral growth if $>100 \mathrm{pg} / \mathrm{ml}$ of $\mathrm{p} 24$ was detected.

\section{RESULTS}

Thirty peripheral blood isolates of HIV-1 were studied. These were obtained from six vertically infected pediatric patients, all of whom progressed rapidly to HIV-1 disease. All children were born between June 1990 and July 1995. There were two females and four males in the cohort; all were of black African American or Caribbean descent. Three of these patients (patients 422,275 , and 601) were presumed to be infected in utero, as virus was detected by culture or viral RNA assay in blood samples obtained within 2 days of birth. The remaining three patients (patients 202, 290, and 217) were apparently infected intrapartum. The patients were assessed for longitudinal progression of clinical disease, occurrence of neurological abnormal- 
TABLE I. Longitudinal Summary of Patient Disease Progression, Neurological Abnormalities, and Cellular Tropism of Isolates

\begin{tabular}{|c|c|c|c|c|c|c|c|c|}
\hline Patient & Age & $\mathrm{m} \phi^{\mathrm{a}}$ & MT- $2^{\mathrm{b}}$ & ast $^{\mathrm{c}}$ & $\mu g l^{d}$ & Co-receptor usage & $\begin{array}{l}\text { CDC } \\
\text { class }^{e}\end{array}$ & $\begin{array}{l}\text { Neurological } \\
\text { abnormalities }\end{array}$ \\
\hline \multirow[t]{7}{*}{202} & $2 \mathrm{wk}$ & + & - & + & - & CCR5 & A & - \\
\hline & $2 \mathrm{mo}$ & + & - & + & + & CCR5 & A & - \\
\hline & $6 \mathrm{mo}$ & Weak+ & - & weak+ & - & CCR5 & B & - \\
\hline & $12 \mathrm{mo}$ & + & - & + & - & CCR5 & B & - \\
\hline & $20 \mathrm{mo}$ & + & + & + & - & CCR5, CXCR4, CCR3 & B & + \\
\hline & $24 \mathrm{mo}$ & + & + & + & + & CCR5, CXCR4, CCR3 & $\mathrm{C}$ & + \\
\hline & $26 \mathrm{mo}$ & + & + & + & - & CCR5, CXCR4, CCR3 & $\mathrm{C}$ & + \\
\hline \multirow[t]{3}{*}{290} & 2 wk & Weak+ & - & - & - & CCR5 & $\mathrm{N}$ & - \\
\hline & $2 \mathrm{mo}$ & Weak + & - & - & - & CCR5 & $\mathrm{C}$ & + \\
\hline & $6 \mathrm{mo}$ & + & - & - & - & CCR5 & $\mathrm{C}$ & + \\
\hline \multirow[t]{3}{*}{601} & Birth & + & - & - & - & CCR5 & $\mathrm{N}$ & ND \\
\hline & $2 \mathrm{mo}$ & + & - & - & - & CCR5 & $\mathrm{N}$ & - \\
\hline & $12 \mathrm{mo}$ & + & - & - & - & CCR5 & $\mathrm{C}$ & ++ \\
\hline \multirow{4}{*}{422} & Birth & + & - & + & + & CCR5 & $\mathrm{N}$ & - \\
\hline & $2 \mathrm{mo}$ & + & - & + & + & CCR5 & B & - \\
\hline & $6 \mathrm{mo}$ & + & - & + & + & CCR5 & $\mathrm{C}$ & ++ \\
\hline & $11 \mathrm{mo}$ & + & - & + & - & CCR5 & $\mathrm{C}$ & ++ \\
\hline \multirow[t]{3}{*}{275} & $2 \mathrm{wk}$ & + & - & - & - & CCR5 & $\mathrm{N}$ & - \\
\hline & $2 \mathrm{mo}$ & + & - & - & - & CCR5 & $\mathrm{N}$ & - \\
\hline & $12 \mathrm{mo}$ & + & - & - & - & CCR5 & $\mathrm{C}$ & + \\
\hline \multirow[t]{8}{*}{217} & $2 \mathrm{wk}$ & Weak+ & - & + & - & CCR5 & $\mathrm{N}$ & - \\
\hline & $2 \mathrm{mo}$ & + & - & - & - & CCR5 & $\mathrm{N}$ & - \\
\hline & $6 \mathrm{mo}$ & + & - & - & - & CCR5 & $\mathrm{C}$ & - \\
\hline & $12 \mathrm{mo}$ & + & - & - & - & CCR5 & $\mathrm{C}$ & + \\
\hline & $24 \mathrm{mo}$ & + & - & - & - & CCR5 & $\mathrm{C}$ & + \\
\hline & $38 \mathrm{mo}$ & + & + & - & - & CCR5, CXCR4, CCR3 & $\mathrm{C}$ & + \\
\hline & $45 \mathrm{mo}$ & + & + & - & - & CCR5, CXCR4, CCR3 & $\mathrm{C}$ & + \\
\hline & $49 \mathrm{mo}$ & + & + & - & - & CCR5, CXCR4, CCR3 & $\mathrm{C}$ & ++ \\
\hline
\end{tabular}

${ }^{\text {a }}$ Primary macrophage tropism.

${ }^{\mathrm{b}}$ T-cell tropism as defined by growth on the T-cell line MT-2, virus that grew in MT-2 cells were also SI.

cPrimary astrocyte tropism.

dPrimary microglia tropism.

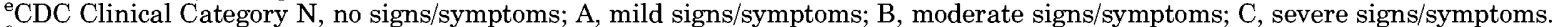

${ }^{\mathrm{f}}$ Neurological abnormalities: - , no abnormalities found; + , developmental delay and/or cognitive abnormalities; ++ , CNS atrophy and/or brain calcification; ND, not determined.

ities, CD4+ lymphocyte count, viral load, and the cellular tropisms of their viral isolates. Table I and Figure 1 (arranged arbitrarily by patient number) summarize the data from all HIV-1 isolates. All children developed a CDC Category C AIDS defining illness [Centers for Disease Control, 1994] during the first 2 years of life. Five of the children died by 30 months of age, and one child (patient 217) still survives. Neurological abnormalities ranging from developmental delay and/or cognitive dysfunction to CNS atrophy and/or brain calcification were found as early as 2 months of age in one child, and in all children by 20 months of age. Therefore, these patients represent a cohort of vertically HIV-1 infected pediatric patients whose clinical disease progressed rapidly and included neurological abnormalities within the first two years of life. Of the five patients that died, four had declining CD4 counts during the course of their illness (Fig. 1). The surviving child (patient 217) is severely immunosuppressed, as evidenced by very low CD4 values. HIV-1 viral load (viral RNA copies/ml) values are available for five of the six children and show progressive increase in viral load in three. Four of the children (patients 422, 601, 202, and 217) received zidovudine monotherapy within the first 4 months of life because of early diagnosis of HIV-1 infection and evidence of clinical disease.

The longitudinal collection of HIV-1 isolates from each patient was assessed for cellular tropism, which was defined by the ability of a given isolate to grow in primary human macrophages, an immortalized human T-lymphocyte cell line (MT-2), primary human astrocytes, and primary human microglia. Between birth and 12 months of age, all six of the children harbored viruses that were macrophage tropic. In the two children who later developed T-tropic viral isolates (patients 202 and 217), progression to severe disease or development of neurological abnormalities did not predict or depend upon the appearance of the T-tropic phenotype. Within the first year of life, patient 202 displayed weak gross motor skills and only later, at 20 months of age, produced viral isolates that had gained T-cell tropism in addition to macrophage tropism (Table I, Fig. 1A). This expanded cellular tropism coincided with the progression to Category $\mathrm{C}$ illness as well as developmental delay. By 38 months of age, this patient had delayed fine motor skills and both expressive and receptive language deficits. In contrast to patient 202, patient 217 did not develop dual tropic viruses (able to infect both macrophages and MT-2 

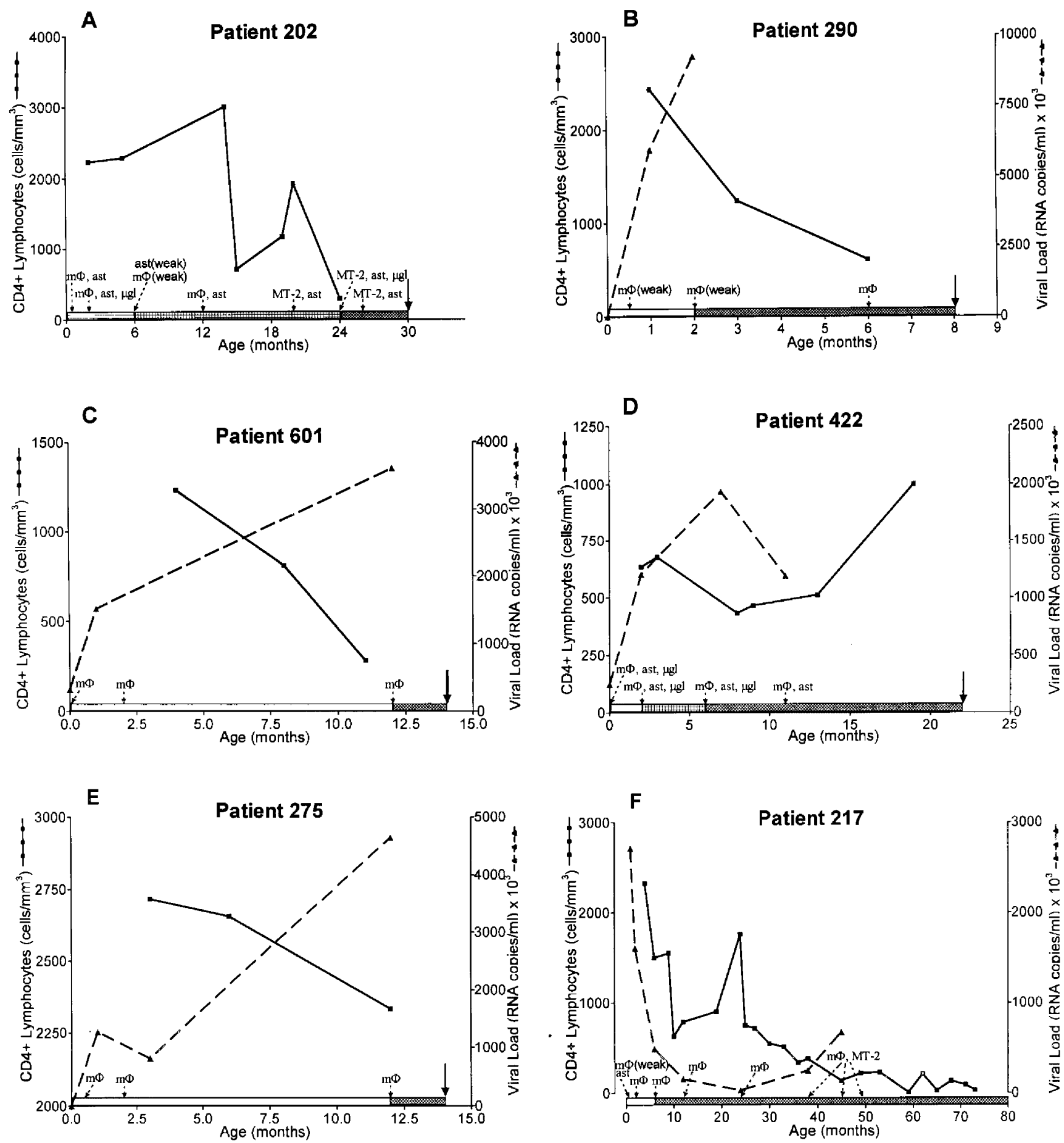

Fig. 1. Individual longitudinal profiles of clinical disease stage, cellular tropisms, CD4+ lymphocyte counts $\left(\right.$ cells $\left./ \mathrm{mm}^{3}\right)$, and human immunodeficiency virus type 1 (HIV-1) viral load (RNA copies/ml) in six vertically infected children with rapid clinical disease progression. Clinical disease stage according to Centers of Disease Control (CDC) classification is indicated along the x-axis: open bar, CDC class N; horizontally striped bar, CDC class A; horizontally cross-hatched bar,

cells) until 38 months of age, about 32 months after progression to severe disease, and 26 months after the appearance of neurological abnormalities (Table I, Fig. 1F). The remaining four children harbored macrophage tropic viruses throughout life, even after pro-

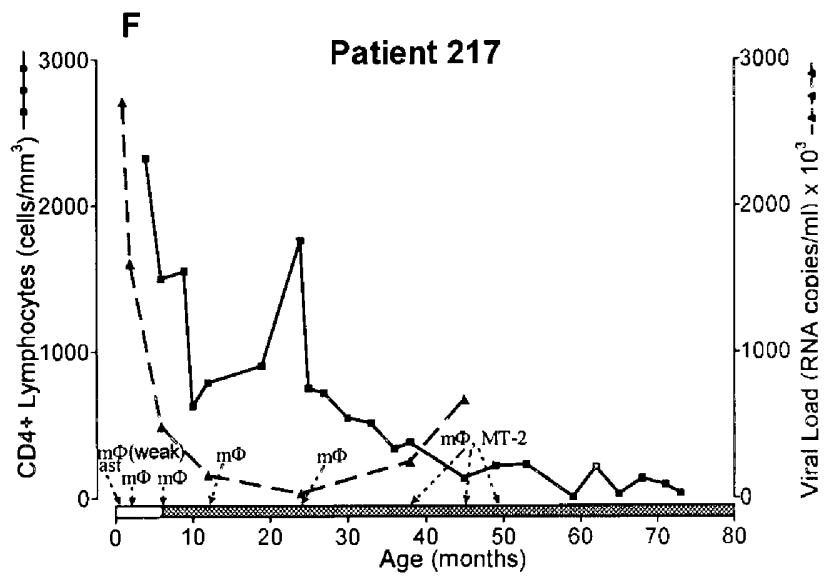

CDC class B; vertically cross-hatched bar, CDC class C; vertical arrow, death. The appearance of viral isolates with specific cellular tropisms are indicated along the x-axis of each profile: $m \Phi$, macrophage (NSI); ast, astrocyte; $\mu \mathrm{gl}$, microglia; MT-2, T-tropic (SI) virus determined by growth in MT-2 cells as described in the Materials and Methods section.

gression to severe disease and the development of neurological abnormalities.

Only two of the six children, patients 202 and 422, ever exhibited viral isolates with cellular tropisms for both astrocytes and microglia (Table I). In these two 
children, astrocyte tropism persisted, whereas microglia tropism was transient. A third child, patient 217, produced astrocyte-tropic isolates within the first 2 weeks of life, but this astrocyte tropism was subsequently lost from later isolates. All microglia-tropic isolates were found to be macrophage-tropic. There was no correlation between a change in neural cell tropism and a change in neurological status. Patient 422 did not harbor T-tropic isolates at any time and consistently produced macrophage-tropic strains. Therefore, we did not observe a correlation between emergence of T-cell tropism and neural cell tropism (astrocytes or microglia) in this cohort.

Additional experiments were performed to define the co-receptor usage of the isolates. All isolates produced by the cohort during the first year of life used the CCR5 co-receptor, which correlated with macrophage tropism and the NSI phenotype (Table I). When patients 202 and 217 developed T-tropic isolates in addition to their macrophage-tropic isolates later in the course of disease, co-receptor usage of their respective isolate populations expanded to include CXCR4 and CCR3, as well as CCR5. Interestingly, all viruses that have evolved to use the CXCR4 co-receptor have also evolved to use CCR3, and there appeared to be a correlation between CCR3 and CXCR4 co-receptor usage, at least in the children that we have tested. In contrast, patients 202, 422, and 217 produced isolates during the first year of life that were microglia- and/or astrocyte-tropic but used only the CCR5 co-receptor. Patient 202 at 2 months, and patient 422 at birth, 2 months, and 6 months, had isolate populations with both astrocyte and microglia tropisms. Thus, diverse neural cell tropisms were seen in viral isolate populations using only CCR5.

\section{DISCUSSION}

In this study of six vertically HIV-1-infected pediatric patients with rapid disease progression, viral phenotype properties did not specifically predict clinical features or course. Macrophage-tropic viral isolates and CCR5 chemokine co-receptor usage predominated and T-tropic (SI) isolates, when they occurred, arose later in the clinical course. There was no correlation between the timing of HIV-1 infection, i.e., in utero versus peripartum, and rapid clinical progression, although, consistent with the Women and Infants Transmission Study [Shearer et al., 1997], all patients had high viral load (>500,000 RNA copies $/ \mathrm{ml}$ ) during the first 2 months of life. Clinical neurological manifestations of HIV-1, i.e., encephalopathy and developmental delay, did not depend on the emergence of virus strains in the peripheral circulation that were infectious for microglia and/or astrocytes in vitro. Macrophage tropism was not equivalent to, nor did it predict, microglia tropism, although in this cohort, all microgliatropic isolates were also macrophage-tropic. Astrocytetropic isolates obtained from three of the six patients (patients 202, 422, and 217) were also macrophage- tropic, and the astrocyte-tropic isolates detected earlier in the disease course used the CCR5 co-receptor only (Table I). Furthermore, rapid disease progression and death occurred in most cases without the emergence of T-tropic (SI) strains at all, and the development of AIDS did not coincide with or depend on the appearance of quasi-species able to infect T-cell lines. When SI strains arose (patients 202 and 217), there was a simultaneous emergence of viruses that acquired dual CXCR4 and CCR3 usage in addition to CCR5. It is not clear whether this is due to a mixture of strains of viruses that each use a different co-receptor, or to a single virus that can use CXCR4 and CCR3 in addition to CCR5. Further cloning of the viruses will be needed to resolve this issue.

These data are consistent with two prior longitudinal studies in vertically HIV-1-infected children [Hutto et al., 1996; Fitzgibbon et al., 1998], and they suggest that progression of HIV-1 illness in very young children frequently does not associate with SI virus phenotype. In a study of 48 children, Fitzgibbon et al. [1998] observed that rapid progressors in that cohort were no more likely to produce SI than NSI viruses, and some rapid progressors died without manifesting SI strains. Hutto et al. [1996] studied viral genetic diversity and cellular tropisms in perinatally infected twins with discordant disease courses, and found that the rapid progressor twin did not produce SI or T-tropic isolates from peripheral blood.

A potential pitfall in the interpretation of our as well as similar studies is the use of viral isolates derived longitudinally from peripheral blood. These blood isolates are a mixed population of quasi-species, and could be expected to exhibit multiple viral phenotypes during the longitudinal course of HIV-1 infection in the individual patient. Given the neuroanatomical sequestration of the CNS, these peripheral blood-derived isolates may not reflect the population of HIV-1 quasispecies resident within the CNS at the time of isolation. Sequestration of the virus in the CNS-resident microglia cells enables local evolution of CNS-specific quasispecies, which may be independent and divergent from peripheral quasi-species [Gonzalez-Scarano and Baltuch, 1999]. However, perivascular microglia at the blood-brain barrier may be exposed to peripheral HIV-1 quasi-species by circulating lymphoid cells [Gonzalez-Scarano and Baltuch, 1999]. Thus, although the peripheral HIV-1 isolates may not reflect the CNS quasi-species at the time of isolation, these peripheral isolates could reflect the circulating subpopulations of HIV-1 that are capable of infecting the blood-brain barrier and entering the CNS as early as birth and throughout the course of disease. Therefore, peripherally derived isolates are potentially relevant to the emergence and progression of clinical neurological disease. In our cohort of six children, the one child with isolate populations that were both astrocyte-tropic and microglia-tropic at birth (patient 422) did have the most rapid onset of more severe neurological abnormalities (CNS atrophy by 6 months of age). 
In this cohort of six pediatric patients with rapid progression of HIV-1-related disease, there was no definitive association between clinical neurological complications and viral phenotype (cell tropism) or coreceptor usage. All six patients in the cohort developed neurological abnormalities, but neural cell tropic viruses were only detected in three patients at any point in life. However, the early and persistent finding of both astrocyte and microglia tropic isolates in one patient (patient 422) did associate with the most rapid progression to CNS atrophy among the six patients. Early (patient 217) or early and persistent (patient 202) astrocyte tropism without microglia tropism did not associate with more rapid presentation of neurological complications. In that peripheral blood-derived isolates may reflect the population of viruses capable of crossing the blood brain barrier and promoting CNS infection, the isolates produced by patient 422 during the first several months of life may have been optimal for seeding, establishing, and amplifying productive infection of the CNS. Microglia-tropic viruses would be capable of establishing productive CNS infection in microglia, while astrocyte-tropic viruses would also establish restricted or latent CNS infection in astrocytes. The combination of these cellular tropisms could ultimately amplify the viral burden in the CNS and accelerate the neurological manifestations of HIV-1 infection in the pediatric patient.

\section{ACKNOWLEDGMENTS}

The authors acknowledge and thank the patients who participated in this study. Irving Vidaurre provided expert technical assistance with microglia and astrocyte cell cultures and p24 antigen assays.

\section{REFERENCES}

AIDS Clinical Trials Group. 1994. ACTG Virology Manual for HIV Laboratories. Division of AIDS, National Institutes of Allergy and Infectious Diseases, September 1994.

Auger I, Thomas P, DeGruttola V, Morse D, Moore D, Williams R, Truman B, Lawrence CE. 1988. Incubation periods for pediatric AIDS patients. Nature $336: 575-577$.

Bagasara O, Lavi E, Bobroski L, Khalili K, Pestaner JP, Pomerantz RJ. 1996. Cellular reservoirs of HIV-1 in the central nervous system of infected individuals: identification by the combination of in situ polymerase chain reaction and immunohistochemistry. AIDS 10:573-585.

Balotta C, Vigano A, Riva C, Colombo MC, Salvaggio A, de Pasquale MP, Crupi L, Papagno L, Galli M, Moroni M, Principi N. 1996. HIV type 1 phenotype correlates with the stage of infection in vertically infected children. AIDS Res Hum Retroviruses 12:1247-1253.

Balotta C, Colombo MC, Colucci G, Vigano A, Riva C, Papagno L, Violin M, Crupi L, Bricalli D, Salvaggio A, Moroni M, Principi N, Galli M. 1997. Plasma viremia and virus phenotype are correlates of disease progression in vertically human immunodeficiency virus type 1-infected children. Pediatr Infect Dis J 16:205211.

Blanche S, Tardieu M, Duliege A-M, Rouzioux C, Le Deist F, Fukunaga K, Caniglia M, Jacomet C, Messiah A, Griscelli C. 1990. Longitudinal study of 94 symptomatic infants with perinatally acquired human immunodeficiency virus infection. Am J Dis Child 144:1210-1215.

Blanche S, Mayaux M-J, Rouzioux C, Teslas J-P, Firtion G, Monpoux F, Ciraru-Visneron N, Meier F, Tricoire J, Courpotin O, Vilmer E, Griscelli C, Delfraissy J-F, and the French Pediatric HIV Infection Study Group. 1994. Relation of the course of HIV infection in children to the severity of the disease in their mothers at delivery. N Engl J Med 330:308-312.

Blumberg BM, Gelbard HA, Epstein LG. 1994. HIV-1 infection of the developing nervous system: central role of astrocytes in pathogenesis. Virus Res 32:253-267.

Cecilia D, Kewalramani VN, O'Leary J, Volsky B, Myambi P, Burda S, Xu S, Littman DR, Zolla-Pazner S. 1998. Neutralization profiles of primary human immunodeficiency virus type 1 isolates in the context of coreceptor usage. J Virol 72:6988-6996.

Centers for Disease Control. 1994. Revised classification system for human immunodeficiency virus infection in children less than 13 years of age. MMWR 43(RR-12):1-10.

Cheng-Mayer C, Weiss C, Seto D, Levy JA. 1989. Isolates of human immunodeficiency virus type 1 from the brain may constitute a special group of the AIDS virus. Proc Natl Acad Sci USA 86:85758579.

Coombs RW, Welles SL, Hooper C, Reichelderfer PS, D'Aquila RT, Japour AJ, Johnson VA, Kuritzkes DR, Richman DD, Kwok S, Todd J, Jackson JB, DeGruttola V, Crumpacker CS, Kahn J. 1996. Association of plasma human immunodeficiency virus type $1 \mathrm{RNA}$ level with risk of clinical progression in patients with advanced infection. AIDS Clinical Trials Group (ACTG) 116B/117 Study Team. ACTG Virology Committee Resistance and HIV-1 RNA Working Groups. J Infect Dis 174:704-712.

De Rossi A, Giaquinto C, Ometto L, Mammano F, Zanotto C, Dunn D, Chieco-Bianchi L. 1993. Replication and tropism of human immunodeficiency virus type 1 as predictors of disease outcome in infants with vertically acquired infection. J Pediatr 123:929 936.

Dickover RE, Dillon M, Gillette SG, Deveikis A, Keller M, PlaegerMarshall S, Chen I, Diagne A, Stiehm ER, Bryson Y. 1994. Rapid increases in load of human immunodeficiency virus correlate with early disease progression and loss of CD4 cells in vertically infected infants. J Infect Dis 170:1279-1284.

Duliege A-M, Messiah A, Blanche S, Tardieu M, Griscelli C, Spira A 1992. Natural history of human immunodeficiency virus type 1 infection in children: prognostic value of laboratory tests on the bimodal progression of disease. Pediatr Infect Dis 11:630-635.

European Collaborative Study. 1991. Children born to women with HIV-1 infection: natural history and risk of transmission. Lancet 337:253-260.

Fitzgibbon JE, Gaur S, Gavai M, Gregory P, Frenkel LD, John JF Jr. 1998. Effect of the HIV-1 syncytium-inducing phenotype on disease stage in vertically-infected children. J Med Virol 55:5663.

Gonzalez-Scarano F, Baltuch G. 1999. Microglia as mediators of inflammatory and degenerative diseases. Annu Rev Neurosci 22: 219-240.

He J, Chen Y, Farzan M, Choe H, Ohagen A, Gartner S, Busciglio J, Yang X, Hofmann W, Newman W, Mackay CR, Sodroski J, Gabuzda D. 1997. CCR3 and CCR5 are co-receptors for HIV-1 infection of microglia. Nature 385:645-649.

Hutto C, Zhou Y, He J, Geffin R, Hill M, Scott W, Wood C. 1996 Longitudinal studies of viral sequence, viral phenotype, and immunologic parameters of human immunodeficiency virus type 1 infection in perinatally infected twins with discordant disease courses. J Virol 70:3589-3598.

Italian Registrar for HIV Infection in Children. 1994. Features of children perinatally infected with HIV-1 surviving longer than 5 years. Lancet 343:191-195.

Katzenstein DA, Hammer SM, Hughes MD, Gundacker H, Jackson JB, Fiscus S, Rasheed S, Elbeik T, Reichman R, Japour A, Merigan TC, Hirsch MS. 1996. The relation of virologic and immunologic markers to clinical outcomes after nucleoside therapy in HIV infected adults with 200 to $500 \mathrm{CD} 4$ cells per cubic millimeter. AIDS Clinical Trials Group Study 175 Virology Study Team [published erratum appears in N Engl J Med 1997;337:1097]. N Engl J Med 335:1091-1098.

Koot M, van't Wout $A B$, Kootstra NA, de Goede RE, Tersmette M, Schuitemaker H. 1996. Relation between changes in cellular load, evolution of viral phenotype, and the clonal composition of virus populations in the course of human immunodeficiency virus type 1 infection. J Infect Dis 173:349-354.

Kuhn L, Abrams EJ, Matheson PB, Thomas PA, Lambert G, Bamji M, Greenberg B, Steketee RW, Thea DM. 1997. Timing of maternalinfant HIV transmission: associations between intrapartum factors and early polymerase chain reaction results. New York 
City Perinatal HIV Transmission Collaborative Study Group. AIDS 11:429-435.

Markham RB, Wang WC, Weisstein AE, Wang Z, Munoz A, Templeton A, Margolick J, Vlahov D, Quinn T, Farzadegan H, Yu XF. 1998. Patterns of HIV-1 evolution in individuals with differing rates of CD4 T cell decline. Proc Natl Acad Sci USA 95:12568-12573.

Mayaux MJ, Burgard M, Teglas JP, Cottalorda J, Krivine A, Simon F, Puel J, Tamalet C, Dormont D, Masquelier B, Doussin A, Rouzioux C, Blanche S. 1996. Neonatal characteristics in rapidly progressive perinatally acquired HIV-1 disease. The French Pediatric HIV Infection Study Group. JAMA 275:606-610.

McCarthy M, Wood C, Fedoseyeva L, Whittemore SR. 1995. Media components influence viral gene expression assays in human fetal astrocyte cultures. J Neurovirol 1:275-285.

McCarthy M, He J, Wood C. 1998. HIV-1 strain-associated variability in infection of primary neuroglia. J Neurovirol 4:80-89.

McNearney T, Hornickova Z, Markham R, Birdwell A, Arens M, Saah A, Ratner L. 1992. Relationship of human immunodeficiency virus type 1 sequence heterogeneity to stage of disease. Proc Natl Acad Sci USA 89:10247-10251.

Morner A, Bjorndal A, Albert J, Kewalramani VN, Littman DR, Inoue R, Thorstensson R, Fenyo EM, Bjorling E. 1999. Primary human immunodeficiency virus type 2 (HIV-2) isolates, like HIV-1 isolates, frequently use CCR5 but show promiscuity in co-receptor usage. J Virol 73:2343-2349.

Mulder-Kampinga GA, Kuiken C, Dekker J, Scherpbier HJ, Boer K, Goudsmit J. 1993. Genomic human immunodeficiency virus type 1 RNA variation in mother and child following intra-uterine virus transmission. J Gen Virol 74:1747-1756.

Newell M, European Collaborative Study. 1991. The natural history of vertically acquired HIV infection. J Perinat Med 19(suppl 1):257262

Nowak MA, Bangham CR. 1996. Population dynamics of immune responses to persistent viruses. Science 272:74-79.

Ohagen A, Ghosh S, He J, Huang K, Chen Y, Yuan M, Osathanondh R, Gartner S, Shi B, Shaw G, Gabuzda D. 1999. Apoptosis induced by infection of primary brain cultures with diverse human immunodeficiency virus type 1 isolates: evidence for a role of the envelope. J Virol 73:897-906.

Ranki A, Nyberg M, Ovod V, Haltia M, Elovaara I, Raininko R, Haapasalo H, Krohn K. 1995. Abundant expression of HIV Nef and Rev proteins in brain astrocytes in vivo is associated with dementia. AIDS 9:1001-1008.

Roos MT, Lange JM, de Goede RE, Coutinho RA, Schellekens PT, Miedema F, Tersmette M. 1992. Viral phenotype and immune response in primary human immunodeficiency virus type 1 infection. J Infect Dis 165:427-432.

Saito Y, Sharer LR, Epstein LG, Michaels J, Mintz M, Louder M, Golding K, Cvetkovich TA. Blumberg BM. 1994. Overexpression of nef as a marker for restricted HIV-1 infection of astrocytes in postmortem pediatric central nervous tissues. Neurology 44:474-480.

Salvatori F, Masiero S, Giaquinto C, Wade CM, Brown AJ, ChiecoBianchi L, De Rossi A. 1997. Evolution of human immunodeficiency virus type 1 in perinatally infected infants with rapid and slow progression to disease. J Virol 71:4694-4706.

Scott G, Hutto C, Makuch R, Mastrucci M, O’Conner T, Trapido E, Mitchell C, Parks W. 1989. Survival in children with perinatally acquired immunodeficiency virus (HIV) infection: experience with 172 children in Miami, Florida. N Engl J Med 321:1791-1796.
Shearer WT, Quinn TC, LaRussa P, Lew JF, Mofenson L, Almy S, Rich K, Handelsman E, Diaz C, Pagano M, Smeriglio V, Kalish LA. 1997. Viral load and disease progression in infants infected with human immunodeficiency virus type 1 . Women and Infants Transmission Study Group. N Engl J Med 336:1337-1342.

Spencer LT, Ogino MT, Dankner WM, Spector SA. 1994. Clinical significance of human immunodeficiency virus type 1 phenotypes in infected children. J Infect Dis 169:491-495.

Strizki JM, Albright AV, Sheng H, O'Connor M, Perrin L, GonzalezScarano F. 1996. Infection of primary human microglia and monocyte-derived macrophages with human immunodeficiency virus type 1 isolates: evidence of differential tropism. J Virol 70: $7654-7662$.

Takahashi K, Wesselingh SL, Griffin DE, McArthur JC, Johnson RT, Glass JD. 1996. Localization of HIV-1 in human brain using polymerase chain reaction/in situ hybridization and immunocytochemistry. Ann Neurol 39:705-711.

Tersmette M, Lange JMA, deGoede REY, de Wolf F, Edfind JKM, Schellekens PTA, Coutinho RA, Huisman HT, Goudsmit J, Meidema F. 1989. Association between biological properties of human immunodeficiency virus variants and risk for AIDS and AIDS mortality. Lancet 1:983-985.

Tornatore C, Nath A, Amemiya K, Major EO. 1991. Persistent human immunodeficiency virus type 1 infection in human fetal glial cells reactivated by T-cell factor(s) or by the cytokines tumor necrosis factor alpha and interleukin-1 beta. J Virol 65:60946100 .

Tornatore C, Chandra R, Berger JR, Major EO. 1994a. HIV-1 infection of subcortical astrocytes in the pediatric central nervous system. Neurology 44:481-487.

Tornatore C, Meyers K, Atwood W, Conant K, Major EO. 1994b. Temporal patterns of human immunodeficiency virus type 1 transcripts in human fetal astrocytes. J Virol 68:93-102.

Tovo P-A, de Martino M, Gabiano C, Cappello N, D'Elia R, Loy A, Plebani A, Zuccotti GV, Dallacasa P, Ferraris G. 1992. Prognostic factors and survival in children with perinatal HIV-1 infection. Lancet 339:1249-1253.

Turner BJ, Denison M, Eppes SC, Houchens R, Fanning R, Markson LE. 1993. Survival experience of 789 children with the acquired immunodeficiency syndrome. Pediatr Infect Dis J 12:310320.

van't Wout $\mathrm{AB}$, Kootstra NA, Mulder-Kampinga GA, Albrecht-van Lent N, Scherpbier HJ, Veenstra J, Boer K, Coutinho RA, Miedema F, Schuitemaker H. 1994. Macrophage-tropic variants initiate human immunodeficiency virus type 1 infection after sexual, parenteral, and vertical transmission. J Clin Invest 94 $2060-2067$.

Whittemore SR, Sanon HR, Wood PM. 1993. Concurrent isolation and characterization of oligodendrocytes, microglia, and astrocytes from adult human spinal cord. Int J Dev Neurosci 11:755-764.

Wolinsky SM, Wike CM, Korber BTM, Hutto C, Parks WP, Rosenblum LL, Kuntsman KJ, Furtado MR, Munoz Л. 1992. Selective transmission of human immunodeficiency virus type-1 variants from mothers to infants. Science 255:1134-1137.

Zhang YJ, Dragic T, Cao Y, Kostrikis L, Kwon DS, Littman DR, KewalRamani VN, Moore JP. 1998. Use of co-receptors other than CCR5 by non-syncytium-inducing adult and pediatric isolates of human immunodeficiency virus type 1 is rare in vitro. J Virol 72:9337-9344. 